\title{
FOREWORD: RECOVERING THE COMMON GOOD
}

\author{
Grant Morris*
}

The first "Recovering the Common Good" Conference was held in Wellington in October 2012. In this Foreword, special editor Dr Morris speaks of the meaning and importance of the topic, and of the conference papers that have been included in this Review.

What is the role of Christians in New Zealand's public life? This question can lead to another question: what is the role of Christians in New Zealand in promoting the common good? If the common good has been lost or weakened in recent times, then the task becomes not just one of promotion, but also recovery. The contributors to this issue of the Victoria University of Wellington Law Review all argue that in New Zealand's increasingly individualistic, neo-liberal and rightsfocused society there is a need to recover the common good.

What is the common good? The contributors to this issue primarily rely on the well-established definition used by the Catholic Church "the sum total of social conditions which allow people, either as groups or as individuals, to reach their fulfilment more fully and more easily." ${ }^{1}$ In Catholic social teaching, the common good involves people working for the benefit of society as a whole, and also for each individual in that society because each individual cannot be separated from the whole. Rather, each individual is an integral part of the whole and without each individual the whole will be weakened. The brilliance of this definition is that it avoids focusing on the whole at the expense of the individual, thus avoiding some of the worst outcomes of utilitarianism and communism. It also avoids focusing on the individual at the expense of the whole, thus avoiding some of the worst outcomes of libertarianism, of capitalist materialism and perhaps even of a liberal, positivist legal system. Catholic social teaching also argues that government exists to promote and ensure the common good. Thus neo-liberal moves towards less state involvement in economic and social life can arguably undermine the common good. But what exactly is the responsibility of the state in 21 st

* Senior Lecturer in Law, Faculty of Law, Victoria University of Wellington.

1 Second Vatican Council "Pastoral Constitution on the Church in the Modern World - Gaudium et Spes" (7 December 1965) at [26]. 
century New Zealand in providing the social conditions, particularly through law, which allow people, in groups and as individuals, to reach fulfilment?

Importantly in the New Zealand context, this intermingling of the whole and the individual is also reflected in Māori tikanga. New Zealand leaders can look to both Christian tradition and Māori customary law to find support for recovering the common good. Will promoting the common good challenge the individualistic focus which appears to dominate economic, legal and social discourse in New Zealand? The articles in this issue answer "yes". Yet while the individualistic focus may be challenged, individual wellbeing will be strengthened because the welfare of the individual is directly linked to the welfare of society. Donne's famous poetic line "No man is an island"2 can be reworded in New Zealand to state that "No New Zealander can thrive in isolation". Societal and personal fulfilment is found in community, or to use Christian terminology, in communion with others. This communion is active and personal, not overly formalised nor purely legal. In particular, this sense of community must extend to those in society who most need the power of the common good. For example, the poor, people with disabilities, prisoners and troubled youth. As Lisa Beech argues, the common good is actually synonymous with helping those in need. Ultimately, we all benefit from the common good.

Christian theology is rich and multi-faceted. It has developed over two millennia and encompasses all aspects of human life, including law and legal systems. In today's secular New Zealand, the attitude of many non-Christians and the media towards Christians is disproportionately influenced by controversy over a small number of issues, in particular, abortion, homosexual rights and euthanasia. These are all vitally important issues that connect to the common good, but they are by no means the only issues on which Christians hold strong opinions. Recovering the common good in a Christian context does imply Christians speaking out in public on important issues but does not require that the issues be limited to those mentioned above. Take for example, the highprofile debate over the legalising of gay marriage. The media fixated on Christian opposition to the Marriage (Definition of Marriage) Amendment Bill 2012, despite the fact that even Christians were divided over the law. In my view, a more productive focus on Christian opinion in these recessionary times relates to poverty and what Christians have to say on this most important issue one which goes to the heart of Biblical teaching and the concept of the common good.

The "Recovering the Common Good" conference was held at Parliament in Wellington in October 2012. The conference was organised by the Christian Lawyers' Association of Wellington and the University of Otago Centre for Theology and Public Issues. ${ }^{3}$ The venue was chosen to emphasise the importance of Christian involvement in public debate and the relationship between

2 John Donne, Meditation XVII (1624).

3 There was also a strong connection with Victoria University of Wellington. Two of the authors in this issue, Māmari Stephens and Grant Morris, are Senior Lecturers in the Faculty of Law. Christopher Marshall is a Professor in Religious Studies at Victoria. 
that involvement and the task of recovering the common good. It also reflected the pivotal role of the legislature and executive in promoting the common good.

The debate was to begin from first principles, that is, what is the common good and does it actually need to be recovered? The central questions for our conference were expressed by Professor Andrew Bradstock in the conference briefing note:

... can economic and social liberalism, with its strong emphasis on individual human rights, provide a

stable basis for a political society? Is a 'good' society one which aims at enabling each individual citizen

to maximise pleasure or freedom, or do we need to take into account those shared moral obligations

which make up the bonds of community, which government must also protect? Is society a series of

disconnected, isolated individuals, or should it also express the value of community cohesion and

solidarity, which comes from sharing a common life together?

A rich and wide-ranging exchange of views occurred at the conference as illustrated by the articles in this publication. Additionally, at the conference, speakers included Tim Costello,(CEO of World Vision Australia), Judge Andrew Becroft (Principal Youth Court Judge), MPs Tim Macindoe (National) and David Clark (Labour), the Most Reverend Philip Richardson (Anglican Bishop of Taranaki and Archbishop of New Zealand), and well-known commentators, Rob Harley and Rod Oram. Titles of presentations included phrases such as "The Common Good in an Age of Individualism", "A Christian in Public Life", and "The Common Good in an Age of Moral Hyperpluralism". There was a clear emphasis on what Christians should be doing to define and recover the common good in a society dominated by an individualistic, even atomistic, and definitely, pluralistic, discourse.

No one answer or viewpoint emerged from the conference, but there was a clear consensus that the common good is a concept worth discussing and worth pursuing. Most contributors expressed scepticism about the way in which our society and legal system often promote individualism over the individual's role in, and connection with, the wider community. Recovering the common good can perhaps lead to a greater balance in New Zealand society and the legal system and a shifting of focus from the specific rights and desires of the individual to the relationship between individuals and community. Perhaps the ultimate outcome might be the realisation that individuals and community are essentially the same thing and unable to be divorced from each other.

The first article in this publication features Bradstock's philosophical overview of the potential place of the common good in contemporary New Zealand society. Bradstock traces the concept of the common good through history but clearly locates its more recent manifestation in Catholic social teaching. After carefully defining what the common good might mean, Bradstock examines the extent to which it could be applied in New Zealand. He astutely notes that the proponents of an individualistic, materialist culture may view the common good as 'illiberal'.

Since the radical economic reforms of 1984-1993, New Zealand's political and legal environment could be described as neo-liberal. Our society has become more unequal despite 
overall economic growth. Bradstock convincingly argues that a greater emphasis on the common good could rebalance our society, placing more emphasis on those in need. This change in emphasis does not need to undermine individualism. In fact, the common good provides that helping those in need improves the well-being of the individual.

Bradstock's exhaustive referencing of relevant sources shows how strong the common good tradition is within the modern Christian Church. The challenge for New Zealand Christians is therefore how to engage with this tradition and use it to make real change. As Bradstock points out, New Zealand church leaders did this publicly in 1993 but the practical effects appear to be limited given the similarities between the social problems of 1993 and those of 2013, for example, child poverty, alcohol abuse, growing wealth disparity and high youth unemployment. ${ }^{4}$ Bradstock concludes by arguing that a Christian perspective should be present in New Zealand public discourse. In particular, this perspective can assist in recovering the common good. This argument was a key reason for the "Recovering the Common Good" conference in 2012.

Lisa Beech's article (based on a joint presentation with the Most Reverend Philip Richardson) approaches the common good from a practical perspective. Beech's experience in working for the Catholic social justice agency, Caritas, enables her to apply common good theory to real-life situations, for example, welfare reform. This practical element effectively allows Beech to act in the way suggested by Bradstock, that is, providing a Christian voice on the common good in public debate. Like Bradstock, Beech's view of the common good is heavily influenced by Catholic social teaching, beginning with Pope Leo XIII's Rerum Novarum encyclical in 1891. Beech challenges the neo-liberal orthodoxy that has existed in New Zealand since the mid-1980s, arguing that it is the opposite of the common good, not because it focuses on the individual, but rather because it divorces the individual from the collective. Through Biblical analogy, careful definitions of related concepts and personal anecdotes, Beech constructs a convincing argument that law reform should be informed by the common good.

This obligation to enhance the common good can also be seen directly in the Gospels. Christopher Marshall argues that it is at the heart of the Good Samaritan parable. Here Jesus takes the specific, reasoned, questions of a lawyer and provides a radical reinterpretation of 'neighbour'. To gain eternal life, one must love thy neighbour both practically and emotionally, as demonstrated by the Samaritan. Marshall sees in this the definition of the common good. While Marshall argues that the full extent of this obligation cannot be dictated through legislation, it nevertheless remains a social and moral duty for all Christians.

As mentioned above, the "Recovering the Common Good" conference acknowledged the need to define the common good before attempting to recover it. John Kleinsman's article challenges us

4 That said, the 1993 Church Leaders' Social Justice Statement clearly inspired Lisa Beech to practical action as detailed in her contribution in this publication. 
to re-think the common good in light of traditional and new approaches to morality. Kleinsman argues that while traditional approaches, often championed by the Christian Church, encompass the common good, they are not necessarily appropriate for modern society. On the other hand, new approaches place too much emphasis on individual rights, placing these rights in conflict with societal well-being. The remedy is to construct a new definition of the common good, which Kleinsman sees reflected in the words of Pope John Paul II. This more conciliatory balance between traditional and new is also in line with the arguments found in Bradstock and Beech. Kleinsman does not find this balance present in some of the arguments relating to assisted reproductive technology in New Zealand. In this area of New Zealand's legal system, he argues that in some instances the new morality prioritises individual interests over societal interests. This moral hyperpluralism can potentially be tempered by the recovery, and re-defining, of the common good.

Māmari Stephens defines the common good as including not only freedom from want, but also freedom to choose to be good. The law plays a key role in facilitating or restricting this second freedom. Stephens argues that this freedom is undermined in New Zealand's social security law by the recent Social Security (Benefit Categories and Work Focus) Amendment Act 2013. This Act creates specific parenting obligations and punishes beneficiaries with benefit cuts or suspensions if the obligations are not fully met. Stephens argues that these types of obligations are not directly linked to the purpose of the social security system and therefore restrict beneficiaries' freedom to choose, thus undermining the common good. New Zealand's Social Security Act 1938 was groundbreaking for its time and preceded many similar schemes in other nations. Prime Minister Michael Joseph Savage referred to his welfare state as "applied Christianity". Stephens views the original system as being consistent with the common good. Repealing these recent legislative changes could therefore help in recovering the common good. In the article, Stephens questions the extent to which it is possible to legislate for this recovery.

The articles presented here approach the common good from the perspectives of philosophy, theology, law reform, life experience and statutory interpretation. Despite this variety of approaches, a strong overarching theme emerges. The common good can be defined and is necessary for an inclusive, successful society. The more we can incorporate the common good into New Zealand public life, the better for everyone, both as individuals and as part of a community. As many contributors point out, the common good is not lost, but its impact is diminished if the individual and the individual's rights are the first priority with little or no reference to wider society. One of the conclusions of this conference is that this is only the beginning of a vital conversation for New Zealand, and for New Zealand's Christian community. On this note, it is very exciting to record that a "Recovering the Common Good II" conference was held in July 2013.

Grant Morris

Special Editor 
